\title{
Enzyme Aided Low Temperature Evaporation for Concentration of Active Proteins from Potato Fruit Juice
}

\author{
Mikko Ahokas, Sanna Taskila, Juha Tanskanen \\ Chemical Process Engineering Research Unit, University of Oulu, Oulu, Finland \\ Email: sanna.taskila@oulu.fi
}

How to cite this paper: Ahokas, M., Taskila, S. and Tanskanen, J. (2018) Enzyme Aided Low Temperature Evaporation for Concentration of Active Proteins from Potato Fruit Juice. Journal of Water Resource and Protection, 10, 846-856. https://doi.org/10.4236/jwarp.2018.109048

Received: July 2, 2018

Accepted: September 4, 2018

Published: September 7, 2018

Copyright $\odot 2018$ by authors and Scientific Research Publishing Inc. This work is licensed under the Creative Commons Attribution International License (CC BY 4.0).

http://creativecommons.org/licenses/by/4.0/

\begin{abstract}
Extraction of starch from potato leads to formation of potato fruit juice (PFJ), which consists of proteins, fibers, starch and water. PFJ contains $1 \%-3 \%$ $[\mathrm{w} / \mathrm{w}]$ of proteins, including protease inhibitors that are potentially valuable for various applications, and could thus bring added value to the potato industry. The use of proteins of PFJ in bioactive form is limited by lack of benign and cost-efficient concentration technologies. The present approach combines a previously introduced low-temperature mechanical vapor compression evaporation technology with option to enzymatic viscosity management in case of high-viscosity fluids. In pilot-scale evaporation, an increase of solid content from $10 \%$ to $40 \%$ was achieved without major technical challenges. The proposed method offers a low-energy means for the concentration potato industry wastewater and reclamation of valuable proteins in active form.
\end{abstract}

\section{Keywords}

Potato Fruit Juice, Evaporation, Concentration, Protein, Wastewater, Enzymatic, Viscosity Management, Starch

\section{Introduction}

Starch industry in EU processes approximately 80 million tons of potatoes every year [1]. Approximately $10 \%$, accounting to 8 million tons, ends up to potato pulp, and over 60 million liters of potato fruit juice (PFJ) are produced. PFJ consists of $1 \%-3 \%$ proteins from which half are valuable protease inhibitors (PIs) [2]. They are used for instance in weight loss promoting products and also medicinal applications have been suggested [3] [4]. Despite high quantities of proteins, fibers, starch and minerals [5], the valorization of PFJ has been rarely con- 
sidered as a truly profitable option. This situation has, however, been changing within the European Union due to novel regulations regarding both end-of waste criteria when processed as biodegradable waste and regulations for nitrogen content when spread to fields. Thus, potato industry is looking for new opportunities that allow less cost intensive use of the side streams.

Conventional protein recovery in starch industry involves phases such as steam pressure coagulation and acid and salt precipitation that lead to denaturation of proteins. After denaturation, these proteins are only of animal feed grade of low value. Via more recent approaches, proteins of PFJ can be concentrated by using chromatographic techniques [6] [7] or solvent extraction [8]. Also micro- and ultrafiltration have been investigated for the purpose [9] [10]. The pre-concentration of $\mathrm{PFJ}$ is advantageous in case of any protein recovery technology.

The selected concentration technique is based on evaporation, a thermal separation method dividing a flow of fluid into condensate and concentrate phases. As compared to traditional evaporation techniques, the present mechanical vapor recompression (MVR) falling film technology employs compressor or fan to compress the vapor after which it may be used as energy source instead of boiler steam. This allows a reasonable energy consumption, practically $10-25$ $\mathrm{kWh} \cdot \mathrm{m}^{-3}[8]$. The condensate will be of potable quality as such or after minor processing. In our previous work, the use of MVR evaporation allowed nearly 6-fold concentration of potato proteins with a minor decrease in the activity of PIs [8], which is a promising indication for the efficiency of technology. However, despite the high efficiency in water removal, the employed falling film evaporation has limitations especially related to the increasing viscosity of the concentrate. Materials with high viscosity, such as starchy solutions or pulp production liquors, are difficult to concentrate using standard evaporators due to limitations of pumps, wetting and fouling [11] [12]. Management of viscosity may thus advance efficient evaporation and pumping of PFJ.

The viscosity reduction of vegetable or fruit solutions is achievable via a selection of techniques. Ultrasound (sonication) treatment reduced the viscosity of $5 \%-10 \%$ starch solution by about two orders of magnitude to $100 \mathrm{cp}$ [13]. Mechanical homogenizer was used to treat evaporated starch concentrate. The viscosity reduction was $13 \%$, leading to lower energy consumption and a concentrate with a higher sugar concentration. In similar way, the evaporation of citrus pulp-wash liquid was enhanced by pre-treatment with enzymes during the pulp washing phase [14]. Enzymes have also been employed to reduce the viscosity prior to fermentation of very high gravity vegetable mashes [11] [15] [16]. In this investigation glucoamylase enzyme was employed to reduce the viscosity of industrial PFJ during MRV evaporation. The feasibility of MVR evaporation was further investigated in pilot-scale at starch industry.

\section{Material and Methods}

\subsection{Potato Fruit Juice}

Potato fruit juice samples were received from Finnish starch industry. Samples 
were initially at $\mathrm{pH} 4.8$. Sulfuric acid was used for the adjustment of $\mathrm{pH}$ to 4.2 or 4.5. The samples were exposed to maximum temperature of $57^{\circ} \mathrm{C}$ at the plant after which they were stored at $4^{\circ} \mathrm{C}$. Native sample contained approximately $14.5 \%$ dry solids from which $14 \%$ were inorganic compounds. During the pilot evaporation, the chemical oxygen demand (COD) values were measured using Hach Lange COD cuvette tests LCK 014 (measuring range $1-10$ g. $\mathrm{L}^{-1}$ ) or LCK 914 (measuring range 5 - 60 g.L $\mathrm{L}^{-1}$ ). Test cuvettes contain all needed reagents: sulphuric acid, potassium dichromate, silver sulphate and mercury sulphate. Sample digestions were carried out with Hach Lange HT $200 \mathrm{~S}$ and spectrophotometric analyses with UV/Vis Spectrophotometer Hach Lange DR 2800.

\subsection{Design of Experiments and Response Surface Modeling}

Response surface methodology (RSM) using MODDE software for Design of Experiments and Optimization (Version 8.0.0.0, UMETRICS AB, Umeå, Sweden) was employed to investigate the effects of growth conditions on protein and amino acid yields. The RSM was prepared using quadratic face centered central composite design (CCF). The performances of the models were evaluated by assessing analysis of variance (ANOVA) as described in [17]. Briefly, with good models, the standard deviation of the model should be much larger than the standard deviation of the noise with its upper confidence level. The effect of a factor can be considered statistically significant if the confidence interval is not larger than the effect itself. Factors under investigation were $\mathrm{pH}$ and the use of glucoamylase enzyme at concentrations of $4.2-4.8$ and $0-600 \mathrm{U} \cdot \mathrm{L}^{-1}$, respectively. The experiment matrix is presented in Table 1.

\subsection{Bench-Scale Evaporation}

The schematic of a typical MVR evaporation process is presented in Figure 1. The process PFJ samples were used for (1) evaporation or (2) enzyme treatment followed by evaporation. In the case of option (2), the enzyme (Amylase AG 300

Table 1. Experiment matrix for RSM.

\begin{tabular}{ccc}
\hline Experiment number & $\mathrm{pH}(\mathrm{rpm})$ & Amylase $\left(\mathrm{U} \cdot \mathrm{L}^{-1}\right)$ \\
\hline N1 & 4.2 & 0 \\
N2 & 4.8 & 0 \\
N3 & 4.2 & 600 \\
N4 & 4.8 & 600 \\
N5 & 4.2 & 300 \\
N6 & 4.8 & 300 \\
N7 & 4.5 & 0 \\
N8 & 4.5 & 600 \\
N9 & 4.5 & 300 \\
N10 & 4.5 & 300
\end{tabular}




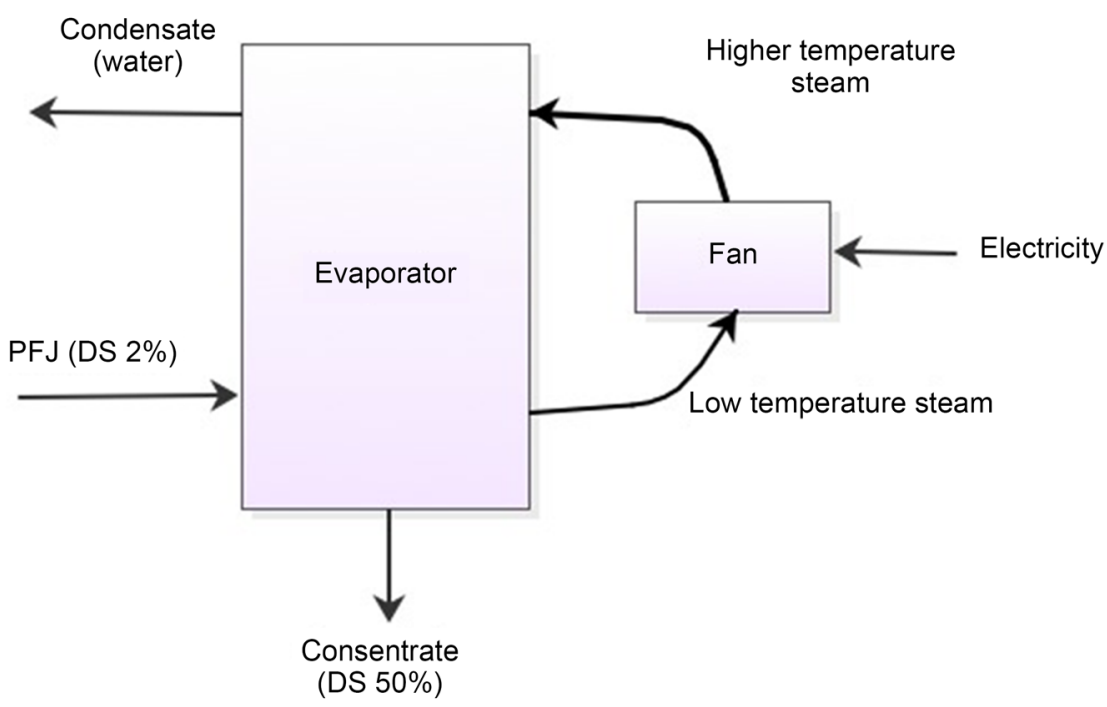

Figure 1. Schematic of the MVR evaporation process. DS-Dry solids. Vacuum is used to allow low temperature evaporation.

L, Novozymes) were added into the samples at levels shown in Table 1, and the solutions were incubated at $50^{\circ} \mathrm{C}$ for $1 \mathrm{~h}$. All samples were centrifuged in $15 \mathrm{~mL}$ reaction tubes at $20^{\circ} \mathrm{C}$ and $15,000 \mathrm{rpm}$ for $5 \mathrm{~min}$ for removal of solids. Evaporation was conducted using BüchiRotavapor R-114 (Büchi, Switzerland) linked to Vacuumbrand PC 3001 VARIO pro vacuum system (Vacuumbrand, Germany) at maximum temperature of $50^{\circ} \mathrm{C}$. Viscosity curves were prepared by measuring the viscosity from the concentrate after adding known amount of water until reaching the theoretic initial viscosity (Brookfield DV-II+ viscometer).

\subsection{Bench-Scale Evaporation}

The flowsheet and items of the 2-stage falling film MVR evaporator used in the pilot-scale evaporation is presented in Figure 2 and Table 2. Technical calculations in this report are based on the material flow of $2.880 \mathrm{~kg} \cdot \mathrm{h}^{-1}$. Total liquid volume was ca. $50 \mathrm{~L}$. The evaporator consists of 19 tubes with length of $4 \mathrm{~m}$ and $3.8 \mathrm{~cm}$ in diameter. Total evaporation surface area was $9 \mathrm{~m}^{2}$. The viscosity of the concentrate was monitored during the evaporation in duplicates by means of DIN 4 viscosity cup (SATA, Germany).

\subsection{Simulation}

Evaporation simulations were carried out using the Simulation Software Fallström 9.5.b6. (Epcon Evaporation Technology AS, Norway). To carry out a simulation, a flow sheet representing the process was created and the flow rates, compositions and temperatures systematically were varied to achieve a steady mass and energy balance consistent with the block and inlet stream specifications. Some unit operations were simulated with general blocks in which the parameters were set based on experimental and estimated performance. The first step in the MVR evaporator simulations was to develop a mass balance, shown 


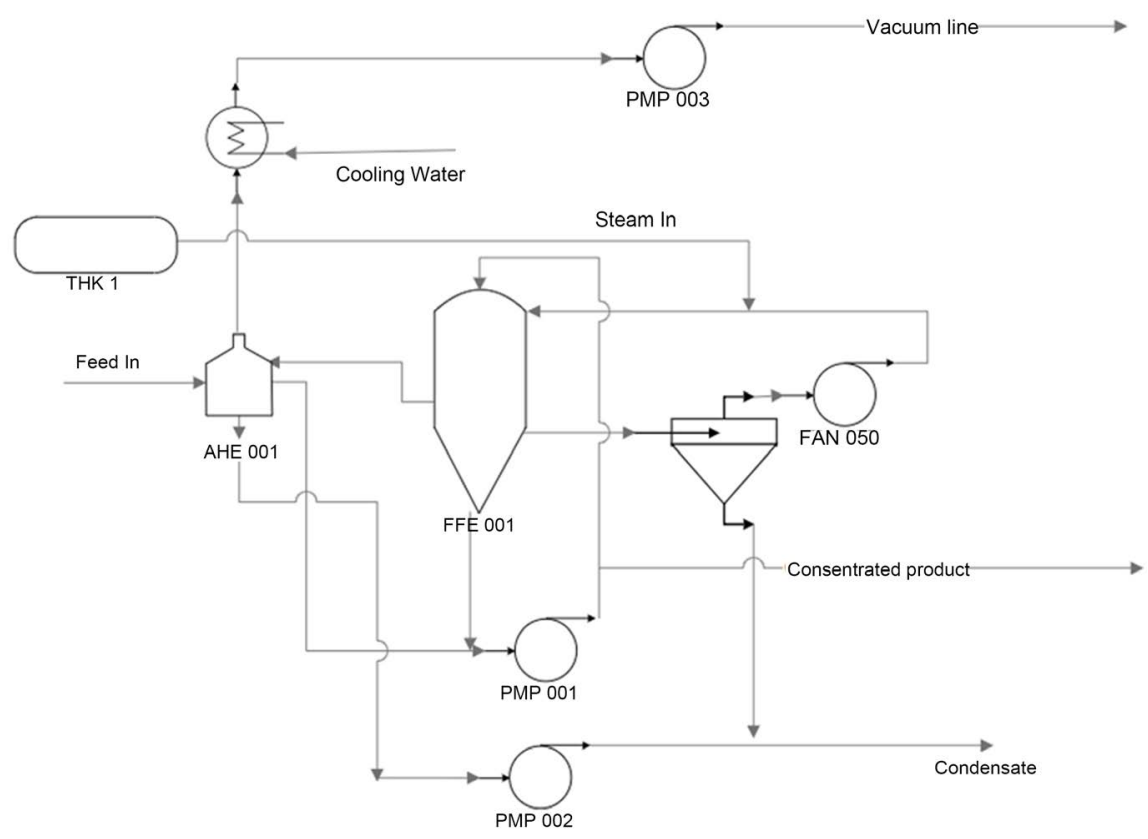

Figure 2. Process flowchart of the MVR evaporation pilot process with items listed in the Table 2.

Table 2. Items of the evaporation system.

\begin{tabular}{|c|c|}
\hline Item & Description and specifications \\
\hline FFE 001 & Heat exchanger \\
\hline PMP 001 & $\begin{array}{l}\text { Centrifugal pump ( } 4.9 \mathrm{~kW} \text { ) for the recycling of feed with constant flowrate of } 3000 \text { - } \\
3500 \mathrm{~kg} \cdot \mathrm{h}^{-1}\end{array}$ \\
\hline FAN 050 & Compressor $(17.3 \mathrm{~kW})$ for steam generation at speed of in maximum $1500 \mathrm{rpm}$ \\
\hline PMP 003 & Vacuum pump $(3 \mathrm{~kW})$ for the generation of vacuum \\
\hline AHE 001 & Preheater of feed, operated using the heat recovered from the condensate \\
\hline PMP 002 & $\begin{array}{l}\text { Centrifugal condensate pump }(1 \mathrm{~kW}) \text { for the removal of condensate from the } \\
\text { compressor }\end{array}$ \\
\hline TNK 001 & Integrated steam generator to decrease the heating time during start-up process \\
\hline
\end{tabular}

in Figure 1. Capital costs were determined first by the following procedure: 1) establish the inlet and outlet conditions; 2) establish the heat transfer coefficients and temperature limits of potato fruit juice; 3 ) determine the required solid content in the final concentrate; 4) calculate the heat input through an energy balance; 5) calculate the heat exchanger and evaporator areas and the compressor power; 6) size miscellaneous equipment.

\subsection{Analysis of Protein Quality}

Soluble proteins were isolated by adding $100 \mathrm{mM}$ sodium phosphate buffer $(\mathrm{pH}$ 7.0) and incubation at $20^{\circ} \mathrm{C}$ and $400 \mathrm{rpm}$ for $1 \mathrm{~h}$. Insoluble fraction was removed by centrifugation. Sodium dodecyl sulphate polyacrylamide gel electrophoresis (SDS-PAGE) was used for the control of produced protein fractions. PageRuler ${ }^{\mathrm{Tm}}$ 
Plus Prestained Protein Ladder (Thermo Scientific) was used as marker in SDSPAGE.

\section{Results and Discussion}

\subsection{Behavior of PFJ during Evaporation}

The behavior of PFJ during the evaporation was initially investigated using bench scale equipment. As can be seen in Figure 3, the viscosity of each fluid increased sharply during the evaporation which is due to the starch in the PFJ. In the pilot evaporation, the solid content of the PFJ could be increased from below 10 up to $40 \%$ without major technical challenges (Table 3 ). The quality of the condensate was investigated in terms of COD. Notably, the COD of the condensate was clearly above the threshold of $150 \mathrm{mg} \cdot \mathrm{L}^{-1}$ for reuse (in-house reference value). Therefore, the reuse of the condensate requires further treatment. The $\mathrm{pH}$ of the condensate ranged at $3.5-4.6$. The solid content remained low during the evaporation.

\subsection{Reduction of Viscosity by Enzymes during Evaporation}

To assess the effect of enzymes on the rheology of solutions during evaporation, the curve data presented in Figure 3 were fit to exponential function and the solid concentrations at viscosity of $50 \mathrm{cp}$ were calculated (Table 4). The values were used in statistical analysis to detect the effects of enzymes and $\mathrm{pH}$ on the rheology of the PFJ (Figure 4). The use of glucoamylase allowed evaporation to higher TS before reaching the critical viscosity of $50 \mathrm{cp}$ (Figure $3, \mathrm{p}<0.05$ ) which result is in line with the previous reports [11] [14] [16]. Although the optimal $\mathrm{pH}$ of the used glucoamylase is around 3.8 , the change of $\mathrm{pH}$ from 4.2 to 4.8 did not affect fluid viscosity at statistically significant level.

The use of enzymes was further investigated in the pilot-scale evaporation. The evaporation was prepared at $50^{\circ} \mathrm{C}$ either without glucoamylase or with addition of $200 \mathrm{~mL}$ glucoamylase into the PFJ. Based on viscosity vs. density curves (Figure 5), the use of enzymes did not affect the rheology of the concentrate.

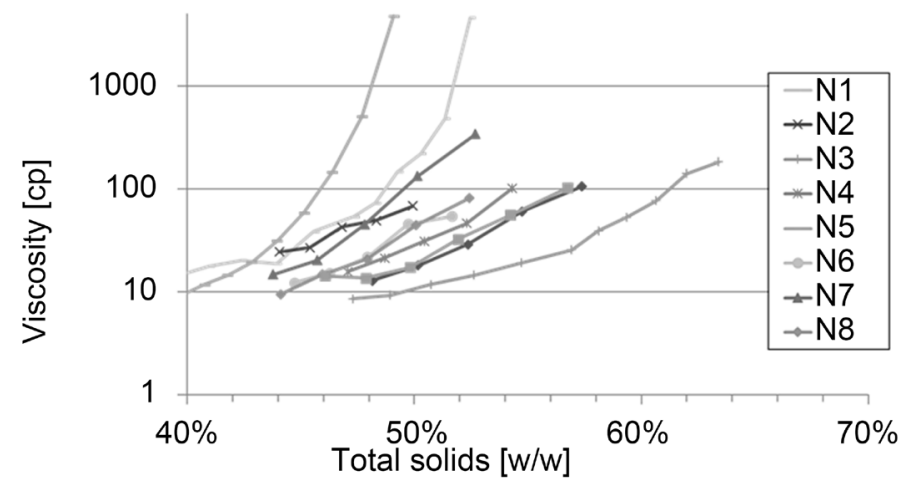

Figure 3. Viscosity vs. total solids in evaporation concentrates. The plots are printed in half logarithmic scale to allow better visual quality of the figure. N1 ... N10 refer to experiment numbers as presented in Table 1 . 
Table 3. The characteristics of concentrate and condensate produced during the pilot evaporation of PFJ measured for 4 hours.

\begin{tabular}{cccc}
\hline Time & $\mathrm{t}=0 \mathrm{~h}$ & $\mathrm{t}=1 \mathrm{~h}$ & $\mathrm{t}=4 \mathrm{~h}$ \\
\hline Concentrate & $>30$ & $>30$ & 44 \\
Brix (\%) & 28 & 25 & $\mathrm{n} / \mathrm{a}$ \\
Viscosity (cp) & 27 & 29 & 40 \\
Total solids (\%) & & \\
Condensate & 40.9 & 40.8 & 63.5 \\
Flow (L·h $\left.{ }^{-1}\right)$ & 0 & 0 & $\mathrm{n} / \mathrm{a}$ \\
Brix $(\%)$ & 4.3 & 3.5 \\
$\mathrm{pH}$ & 4.6 & 528 & 570 \\
COD $\left(\mathrm{mg} \cdot \mathrm{L}^{-1}\right)$ & 544 & & \\
\hline
\end{tabular}

Table 4. Analysis of the rheological behaviour of each suspension during evaporation. The values for $\mathrm{pH}$, enzyme concentration (Amy), total solid content at the beginning of evaporation (TSSTART, w/w), calculated solid concentration at viscosity of $50 \mathrm{cp}(\mathrm{TS} \mu=$ 50) based on exponential fit, fit equation and respective R-squared value are presented for each experiment. (95\% confidence)

\begin{tabular}{ccccccc}
\hline Experiment & $\mathrm{pH}$ & Amylase & $\mathrm{TS}_{\text {START }}(\%)$ & $\mathrm{TS}_{\mu=50}(\%)$ & Exponential fit equation & $\mathrm{R}^{2}$ \\
\hline 1 & 4.2 & 0 & 51.9 & 58.2 & $\mathrm{y}=10^{-8} \times \mathrm{e}^{38.361 \mathrm{x}}$ & 0.75 \\
2 & 4.8 & 0 & 71.9 & 74.4 & $\mathrm{y}=2 \times 10^{-9} \times \mathrm{e}^{32.192 \mathrm{x}}$ & 0.96 \\
3 & 4.2 & 600 & 49.6 & 59.3 & $\mathrm{y}=4 \times 10^{-5} \times \mathrm{e}^{23.65 \mathrm{x}}$ & 0.90 \\
4 & 4.8 & 600 & 74.8 & 77.1 & $\mathrm{y}=6 \times 10^{-17} \times \mathrm{e}^{53.517 \mathrm{x}}$ & 0.96 \\
5 & 4.2 & 300 & 63.2 & 66.6 & $\mathrm{y}=3 \times 10^{-22} \times \mathrm{e}^{80.344 \mathrm{x}}$ & 0.86 \\
6 & 4.8 & 300 & 74.9 & 78.1 & $\mathrm{y}=2 \times 10^{-15} \times \mathrm{e}^{48.344 \mathrm{x}}$ & 0.96 \\
7 & 4.5 & 0 & 75.5 & 59.4 & $\mathrm{y}=4 \times 10^{-5} \times \mathrm{e}^{23.65 \mathrm{x}}$ & 0.90 \\
8 & 4.5 & 600 & 77.9 & 81.0 & $\mathrm{y}=10^{-20} \times \mathrm{e}^{61.686 \mathrm{x}}$ & 0.98 \\
9 & 4.5 & 300 & 78.0 & 80.2 & $\mathrm{y}=2 \times 10^{-20} \times \mathrm{e}^{61.441 \mathrm{x}}$ & 0.98 \\
10 & 4.5 & 300 & 76.4 & 79.6 & $\mathrm{y}=2 \times 10^{-15} \times \mathrm{e}^{47.443 \mathrm{x}}$ & 0.92 \\
\hline
\end{tabular}

Two additional experiments were conducted in which an additional $200 \mathrm{~mL}$ of the enzyme was dosed at density of around $1200 \mathrm{~kg} \cdot \mathrm{m}^{-3}$ (corresponding to ca. $40 \%$ solid content). Some re-shape of the viscosity curve may be observed after the second enzyme dosing. The dosage of enzyme may be of interest in the further research. Moreover, the seasonal variation in the PFJ causes some changes in the starch content [18] which in turn would influence on the feasibility of the glucoamylase in the viscosity management during evaporation. Thus, it would be advantageous to investigate the effect and dosage of the enzymes for larger variety of PFJ samples.

\subsection{The Quality of the Proteins in Concentrate}

The quality of the concentrate was assessed in terms of quality of the proteins 


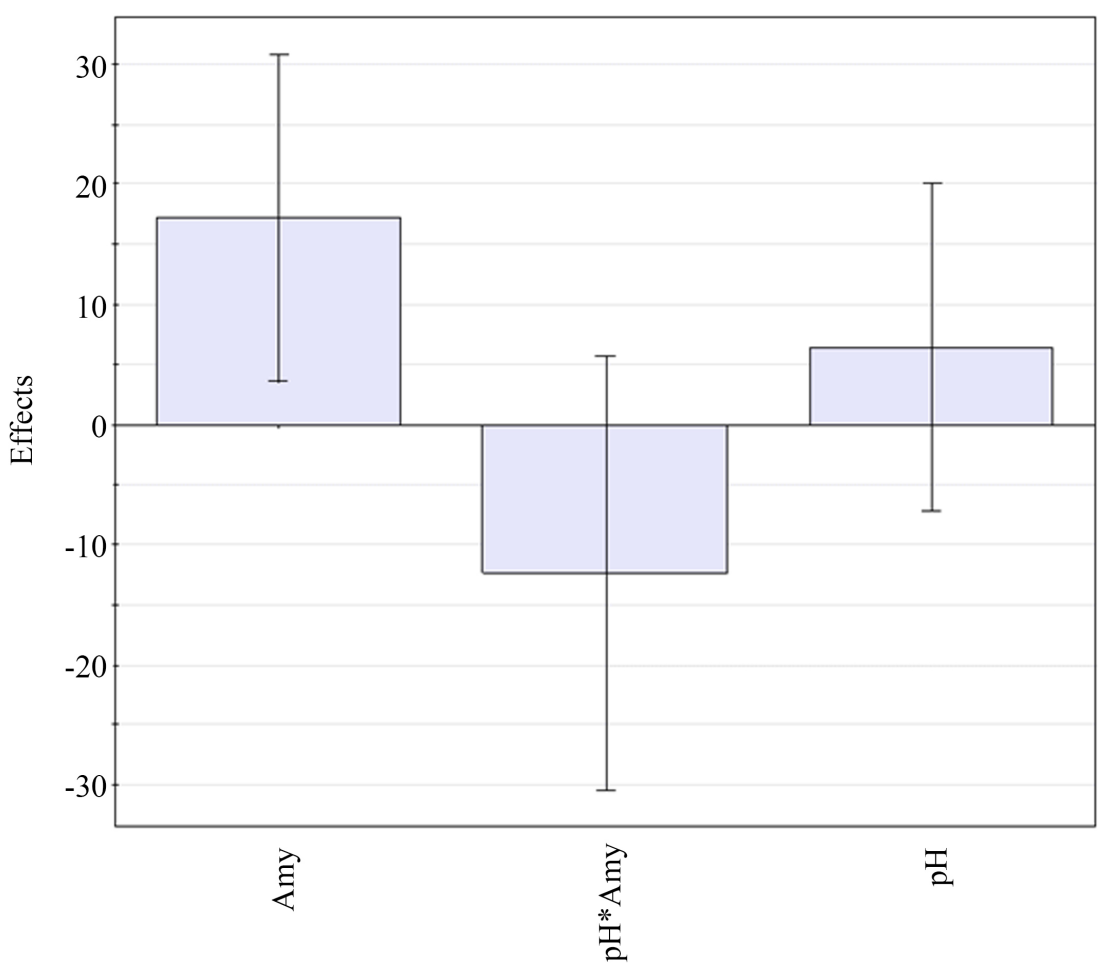

Figure 4. The scaled effects of $\mathrm{pH}$ and glucoamylase on the total solid concentration at viscosity of $50 \mathrm{cp}$ in bench-scale evaporation. The scaled effects of the model terms are presented at 95\% confidence level. Amy-glucoamylase, $\mathrm{pH}^{\star} \mathrm{Amy}$-interaction term of $\mathrm{pH}$ and glucoamylase.

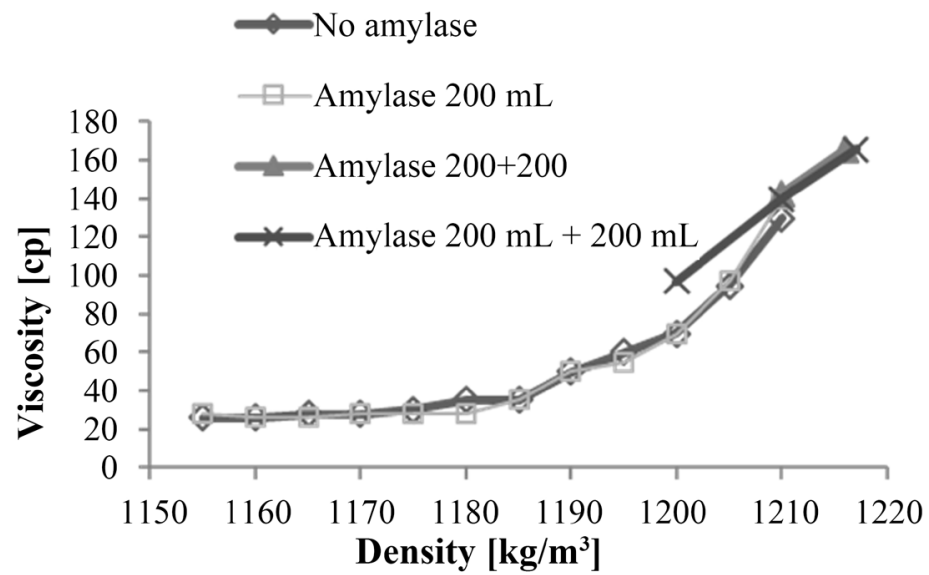

Figure 5. Viscosity vs. density of PFJ during the pilot evaporation. The viscosity curves without amylase and with $200 \mathrm{~mL}$ are shown. Two experiments were included in which an additional $200 \mathrm{~mL}$ of amylase was added later into the PFJ.

after evaporation. Based on the protein bands observed on SDS-PAGE (Figure 6), soluble PIs were recovered from all concentrates. The intensity of bands suggests that significant portion of the PIs were precipitated during the concentration phases (Figure 6(a)), but were resoluble to the sodium phosphate buffer (Figure 6(b)). Patatin bands respective to $\mathrm{pH} 4.2$ were minor or inexistent in the 


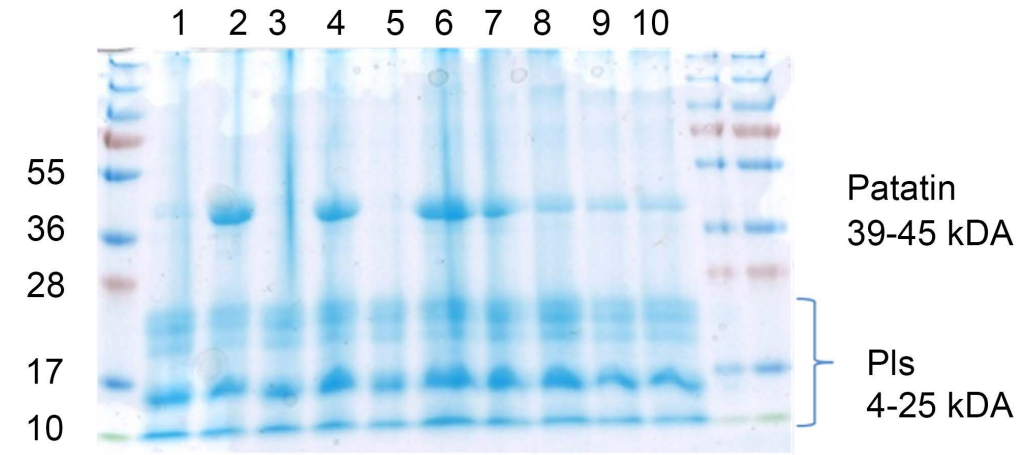

(a)

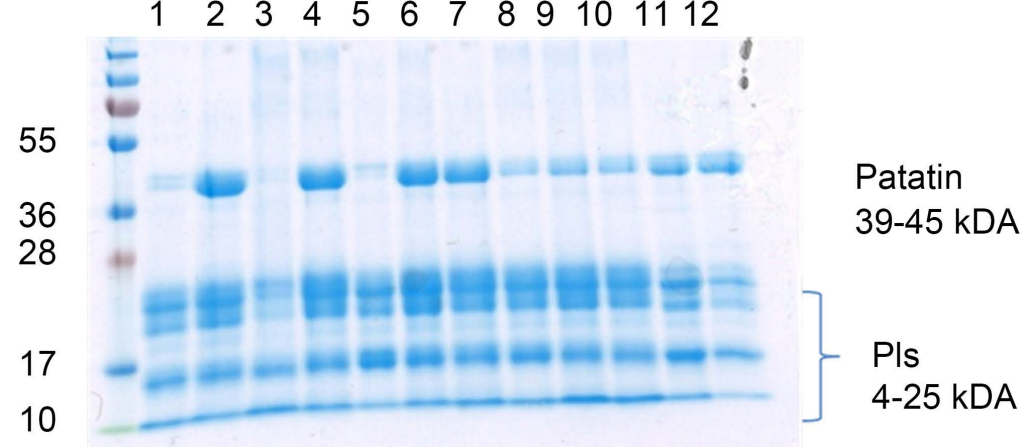

(b)

Figure 6. SDS-PAGE gels of soluble (a) and precipitated but resoluble (b) proteins in PFJ concentrates after evaporation. $1 \ldots 10$-Experiments $1 \ldots 10,11-$ original sample at $\mathrm{pH}$ $4.2,12$-original sample at $\mathrm{pH} 4.8$.

gel. The result is well in line with findings of other scientists [19], suggesting that decrease of $\mathrm{pH}$ to 4.2 allowed more selective removal of patatin from PFJ and thus contributed to isolation of PIs. The employed enzyme assisted evaporation enabled the concentration of resoluble PIs for further processing as was proposed in our previous report [8].

\section{Conclusion}

The present results suggest that the use of enzymes during the evaporation of PFJ leads to lower viscosity and allows more efficient water removal from the concentrate. The starch-rich potato fruit juice was concentrated in pilot scale up to $40 \%$ solid content without major challenges. Furthermore, the proposed lowtemperature evaporation method was proven as a useful means for the concentration of proteins without major activity loss. The produced evaporation condensate water phase may be re-used after reduction of COD to an appropriate level.

\section{Acknowledgements}

This research was financed by the European Regional Development Fund project A70161. 


\section{Conflicts of Interest}

The authors declare no conflicts of interest regarding the publication of this paper.

\section{References}

[1] Alt, V., Steinhof, R., Lotz, M., Ulber, R., Kasper, C. and Scheper, T. (2005) Optimization of Glycoalkaloid Analysis for Use in Industrial Potato Fruit Juice Down Streaming. Engineering in Life Sciences, 5, 562-567. https://doi.org/10.1002/elsc.200520107

[2] Ralet, M.C. and Gueguen, J. (1999) Potato Proteins: Composition, Recovery and Functional Properties. Sciences des Aliments, 19, 147-165.

[3] Ahokas, M., Välimaa, A.L., Lötjönen, T., Kankaala, A., Taskila, S. and Virtanen, E. (2014) Resource Assessment for Potato Biorefinery: Side Stream Potential in Northern Ostrobothnia. Agronomy Research, 12, 695-704.

[4] Schieber, A. and Saldana, M.A. (2009) Potato Peels: A Source of Nutritionally and Pharmacologically Interesting Compounds-A Review. Food, 3, 23-29.

[5] Bergthaller, W., Witt, W. and Goldau, H. (1999) Potato Starch Technology. StarchStärke, 51, 235-242.

https://doi.org/10.1002/(SICI)1521-379X(199907)51:7<235::AID-STAR235>3.0.CO; $\underline{2-7}$

[6] Straetkvern, K.O. and Schwarz, J.G. (2012) Recovery of Native Potato Protein Comparing Expanded Bed Adsorption and Ultrafiltration. Food and Bioprocess Technology, 5, 1939-1949. https://doi.org/10.1007/s11947-010-0494-2

[7] Schoenbeck, I., Graf, A.M., Leuthold, M., Pastor, A., Beutel, S. and Scheper, T. (2013) Purification of High Value Proteins from Particle Containing Potato Fruit Juice via Direct Capture Membrane Adsorption Chromatography. Journal of Biotechnology, 168, 693-700. https://doi.org/10.1016/j.jbiotec.2013.09.018

[8] Taskila, S., Ahokas, M., Järvinen, J., Toivanen, J. and Tanskanen, J.P. (2017) Concentration and Separation of Active Proteins from Potato Industry Waste Based on Low-Temperature Evaporation and Ethanol Precipitation. Scientifica.

[9] Schmidt, J.M., Greve-Poulsen, M., Damgaard, H., Hammershöj, M. and Larsen, L.B. (2016) Effect of Membrane Material on the Separation of Proteins and Polyphenol Oxidase in Ultrafiltration of Potato Fruit Juice. Food and Bioprocess Technology, 9 , 822-829. https://doi.org/10.1007/s11947-015-1670-1

[10] Dabestani, S., Arcot, J. and Chen, V. (2017) Protein Recovery from Potato Processing Water: Pre-Treatment and Membrane Fouling Minimization. Journal of Food Engineering, 195, 85-96. https://doi.org/10.1016/j.jfoodeng.2016.09.013

[11] Srichuwong, S., Fujiwara, M., Wang, X., Seyama, T., Shiroma, R., Arakane, M., et al. (2009) Simultaneous Saccharification and Fermentation (SSF) of Very High Gravity (VHG) Potato Mash for the Production of Ethanol. Biomass and Bioenergy, 33, 890-898. https://doi.org/10.1016/j.biombioe.2009.01.012

[12] Ribatski, G. and Jacobi, A.M. (2005) Falling-Film Evaporation on Horizontal Tubesâ-A Critical Review. International Journal of Refrigeration, 28, 635-653. https://doi.org/10.1016/j.ijrefrig.2004.12.002

[13] Iida, Y., Tuziuti, T., Yasui, K., Towata, A. and Kozuka, T. (2008) Control of Viscosity in Starch and Polysaccharide Solutions with Ultrasound after Gelatinization. Innovative Food Science \& Emerging Technologies, 9, 140-146. https://doi.org/10.1016/j.ifset.2007.03.029 
[14] Braddock, R.J. and Kesterson, J.W. (1976) Enzyme Use to Reduce Viscosity and Increase Recovery of Soluble Solids from Citrus Pulp-Washing Operations. Journal of Food Science, 41, 82-85. https://doi.org/10.1111/j.1365-2621.1976.tb01106.x

[15] Poonsrisawat, A., Wanlapatit, S., Paemanee, A., Eurwilaichitr, L., Piyachomkwan, K. and Champreda, V. (2014) Viscosity Reduction of Cassava for Very High Gravity Ethanol Fermentation Using Cell Wall Degrading Enzymes from Aspergillus aculeatus. Process Biochemistry, 49, 1950-1957. https://doi.org/10.1016/j.procbio.2014.07.016

[16] Zhang, L., Zhao, H., Gan, M., Jin, Y., Gao, X., Chen, Q., et al. (2011) Application of Simultaneous Saccharification and Fermentation (SSF) from Viscosity Reducing of Raw Sweet Potato for Bioethanol Production at Laboratory, Pilot and Industrial Scales. Bioresource Technology, 102, 4573-4579.

https://doi.org/10.1016/j.biortech.2010.12.115

[17] Eriksson, L., Johansson, E., Kettaneh-Wold, N., Wikström, C. and Wold, S. (2000) Design of Experiments. Principles and Applications, Learn Ways AB, Stockholm.

[18] Kangas, A., Laine, A, Niskanen, M., Salo, Y., Vuorinen, M., Jauhiainen, L., et al. (2008) Results of Official Variety Trials 2001-2008. ISBN 978-952-487-210-2. MTT Agrifood Research Finland.

[19] Ralet, M.C. and Gueguen, J. (2000) Fractionation of Potato Proteins: Solubility, Thermal Coagulation and Emulsifying Properties. Lebensmittel-Wissenschaft UndTechnologie-Food Science and Technology, 33, 380-387. https://doi.org/10.1006/fstl.2000.0672 